\title{
The Impact of (Jazz) Festivals: an Arts and Humanities Research Council-
}

\section{funded research report}

\begin{abstract}
Festivals are an essential part of the jazz world, forming regularly occurring pivot points around which jazz musicians, audiences, and organizers plan their lives. Funded by the UK's Arts and Humanities Research Council, the purpose of this report is to chart and critically examine available writing about the impact of jazz festivals, drawing on both academic and 'grey'/cultural policy literature in the field. The review presents research findings under the headings of economic impact; socio-political impact; temporal impact and intensification and transformation of experience; creative impact - music and musicians; discovery and audience development; place-making; the mediation of jazz festivals; and environmental impact. It concludes with a set of recommendations for future research, which identifies gaps in the field. To accompany the article, a 100-entry 40,000 word annotated bibliography has also been produced, which is freely accessible online.
\end{abstract}




\section{The Impact of (Jazz) Festivals: an Arts and Humanities Research Council-}

\section{funded research report}

Positively it has been enriching my life more than anything else. I mean, specifically festivals and jazz festivals especially (50-year-old male audience member, EFG London Jazz Festival, 2015).

You very rarely get, in any genre, whatever the festival is of - music, dance, theatre - that experience of wall-to-wall, nonstop, noon till midnight and beyond. You kind of throw yourself open to it, don't you? You kind of throw yourself in ... If you like something, to have so much of it, in a collection of places and being around people who also want that, it's quite a lovely human activity to be part of that (Steve Mead, Director, Manchester Jazz Festival, 2016).

Festivals are an essential part of the jazz world (Frith 2007: 4) and serve as a 'showcase, a creative destination and an attraction for visitors' (Van Aalst and van Melik 2011: 197). Figures vary, but 200 jazz festivals taking place in Britain annually is regularly cited (Riley and Laing 2006, 2010) - although one authoritative listings website has fewer than half that number (91) for the United Kingdom in 2015 (jazzfests.net 2015) - and over 150 jazz festivals take place in Austria, Norway, The Netherlands, and Denmark combined (Rhythm Changes 2013b). Globally, albeit not just inclusive of jazz festivals, there was a $30 \%$ rise in the number of recorded 'cultural festivals' from 1996 to an estimated 10,000 in 2006, of which half could demonstrate some degree of international recognition (AEA Consulting 2006: 16), and an increasing amount of academic interest around festivals and impact from a variety of disciplines (cf Getz 2010). From an initial focus on the economic impacts of 
cultural experiences in the 1980s and 1990s through to a broader assessment of impact which considers instrumental and intrinsic value (Carnwath and Brown 2014), the literature shows that festivals play a significant economic, social and cultural role at local and international levels.

For the purposes of this article, jazz festivals are those with 'jazz' in the title or which predominantly programme jazz and jazz-related music; the article has not been restricted to any particular country, however. Many jazz festivals take place in existing venues such as concert halls and clubs, with some 'mobile spaces' (Kronenburg 2011) in use, but jazz festivals are relatively unlikely to be greenfield camping festivals. This focus on a single (admittedly broad) genre thus ensures that the article gathers together festivals of a broadly similar type and hence, as far as possible, impact.

This research report is based on a literature review which necessarily spans different disciplines, different types of event, and different geographical locations, and which is used as a basis for a comparative assessment of knowledge and conclusions about the impact of jazz festivals. The search was limited to literature in English but encompasses jazz festivals beyond the UK and Europe, partly because a review of literature on British jazz festivals alone would make for scant reading, but, more constructively, because there was also interesting research being done elsewhere. Literature was restricted to academic books and journals, and grey literature, but, due to space limitations, does not include newspaper or magazine articles, therefore generally excludes publications such as Down Beat. Library databases searched include the British Library, the Bodleian Library, the University of East Anglia, and Oxford Brookes University, as well as the Public Library Initiative (http://freetoviewjournals.pls.org.uk). Databases searched include the resources 
sections of the websites of Arts Council England (http://www.artscouncil.org.uk), Creative Scotland (http://www.creativescotland.com), Arts Council of Wales (http://www.arts.wales), Live Music Exchange (http://livemusicexchange.org/resources) and the National Alliance of Arts, Health and Wellbeing (http://www.artshealthandwellbeing.org.uk/resources).

The research was undertaken as part of an Arts and Humanities Research Councilfunded project called The Impact of Festivals (2015-16), in which Webster was the postdoctoral researcher and McKay the principal investigator. The larger project - of which this piece specifically on jazz festivals is but one output - was undertaken in collaboration with research partner the EFG London Jazz Festival, as part of the AHRC's collaborative Connected Communities programme. A small number of extracts from interviews Webster undertook for The Impact of Festivals project more widely are included as 'pull quotes', epigraphs for illustrative purposes.

To enhance what we hope will be the usefulness of the article for other researchers interested in jazz festivals, and festivals more widely, we have produced also an annotated bibliography of over 100 entries which is freely accessible on the project website (http://impactoffestivals.wordpress.com/project-outputs), as well as on the following other sites: UEA institutional repository, http://georgemckay.org, Cultural Heritage and Improvised Music in European Festivals project website (http://chimeproject.eu), McKay's academia page (http://eastanglia.academia.edu/GeorgeMcKay) and on the Live Music Exchange (http://www.livemusicexchange.org). This annotated bibliography provides brief summary and critical material about every bibliography entry. 
Further it is worth noting that this report has a partner, also an output of The Impact of Festivals project, entitled From Glyndebourne to Glastonbury: The Impact of British Music Festivals (Webster and McKay 2016), which is both more wide-ranging (all kinds of music festivals, including some jazz) and narrower in scope (British festivals only). From Glyndebourne to Glastonbury has its own freely accessible and searchable annotated bibliography, via the project website and other online portals above.

Literature on the impact of jazz festivals tends to come from two broad camps. First is the more quantitatively-based research on economic impact and audience motivation from tourism studies and event management, in which the work of Donald Getz has been of particular importance for festival studies. ${ }^{1}$ A number of economic impact reports can also be found within the grey literature, more recently broadened to encompass social and cultural impacts as well. Second is the more qualitativelybased research from anthropology, sociology and cultural studies, often taking starting points from Raymond Williams' ideas about culture and society (1958), Mikhail Bakhtin's concept of the carnivalesque (1968), Victor Turner's notion of communitas (1982), and current theorizations around the process of 'festivalization' (Bennett, Taylor and Woodward 2014). Urban studies is also a source of literature; accounts tend either to be celebratory, focusing on the economic and place-making benefits of festivals, or more critical, in which festivals are instruments of hegemonic power which shift focus from everyday social problems (Gotham 2005). Overall the

\footnotetext{
1 In a review of literature about festivals in general, Getz finds three discourses at play: sociologically/anthropologically based discourses on the roles, meanings and impacts of festivals in society and culture; festival tourism; and festival management (2010).
} 
number and range of disciplines present in this report indicate and confirm that the space of the festival is one of remarkable interdisciplinary interest.

One of our broader findings is that there is more work on the impact of festivals within the folk and pop literature (rock, jazz, 'world', etc.) than from the classical/opera literature, the latter of which have 'traditionally been concerned with works and composers rather than the performance and concert context' (Doctor et al 2007: 6). Another finding is the high proportion of tourism studies literature for jazz festivals (for example, Saleh and Ryan 1993; Formica and Uysal 1996; Saayman and Rossouw 2010; Bracalente et al 2011), indicating the use of jazz festivals as a means for attracting tourists and sponsorship, and for other social and cultural benefits (for example, Curtis 2010; Keogh 2014; Vestrum 2014). The Cape Town International Jazz Festival, for example has a threefold purpose: to provide a jazz experience for the tourists and visitors, to develop the community and to grow the local economy (Saayman and Rossouw 2010: 255).

The report considers impacts on local and regional economic and cultural competitiveness, and presents the impact of festivals on both the temporary and the permanent communities which live at the festival location. It also considers how impact can develop over the history of a festival and the processes through which arts and humanities research (including practice-based work) has impacted on festivals. However, the impact of festivals - inherently temporally and spatially limited events (Getz 2008: 404) - should not easily be overstated. As one commentator mused on the impact of Australia's Wangaratta Jazz Festival on jazz education in the city: 'I expect it is very much like a circus, it arrives and then leaves and no one takes up juggling' (cited in Curtis 2010: 109). It is also worth reiterating 
the inherent problems in generalising from a relatively small number of internationally diverse case studies which include urban and rural festivals.

It is also important to acknowledge the external impacts on festivals, such as economy (cf Lyck, Long and Grige 2012), public policy (cf Ilczuk and Kulikowska 2007; Washburne 2010; Rhythm Changes 2013b), and even natural disasters (Regis and Walton 2008; Porter 2009). Taking such an ‘ecological approach’ (Webster 2011; Behr et al 2016) allows for a broader understanding of the internal and external constraints on festivals and hence restraints on the potential for impact.

\section{A typology of impacts}

We now turn attention to our core work, which is to present in a structured overview our findings about the kinds of impact jazz festivals have had. We have categorized these into eight areas. We do pay particular attention to economic impact, as we recognize the pragmatic interest in such data, and are able to include in that section a table specifically of impact reports. But we place such material alongside other altogether less tangible values and impacts: jazz festival as transformative subjective experience, for instance.

\section{Economic impact}

The situation with the arts is that the festivals have money and sponsorship and promotion, so they can afford to bring international art. Individual venues [like small clubs] very seldom can do that (47-year-old female EFG London Jazz Festival-goer, 2015).

Jazz festivals increase visitor and local spend in a locale both via increased spend from locals and from increased visitor/tourist spend on accommodation, food, fuel, 
shopping, souvenirs and local products and produce (Curtis 2010: 109). Indeed, work in the UK on the live music industries as a whole put the total direct and indirect spend generated by 'music tourism'2 in the UK in 2014 at $£ 3.1$ billion, sustaining 38,238 full time jobs (UK Music 2015: 7). During 2006-2007, an estimated £41.8m was spent by arts festivals in the UK, including jazz festivals (sam and the University of Brighton 2008: 5), and, focusing on jazz, it has been estimated that the total economic impact of Europe Jazz Network members' direct spending in 2009 was $€ 340$ million (NB this aggregated total includes national jazz organizations and large and small festivals) (Goh 2012: 34).

The usefulness of empirical assessments of economic impact to policy makers and to local development is apparently 'without doubt' (Bracalente et al 2011: 1235) but aggregation of studies is problematic because the relative lack of case studies and the heterogeneous nature of the methodological approaches (for example, Jones and Munday 2004; Saayman and Rossouw 2010) means that it is difficult to both generalize and to compare across festivals (Bracalente et al 2011: 1235-6). In addition, economic impact reports tend towards the positive benefits of the festivals they assess but tend to avoid or ignore any 'typicality' of arts and culture festivals they could be about any kind of event; artistic or not (Vrettos 2006: 6). Furthermore, the propensity to go out of date mean that economic impact assessments can only ever be regarded as one piece of the impact jigsaw.

The following list shows some of the results of economic impact assessments for jazz festivals but with the caveat that the different methodologies employed by each

\footnotetext{
${ }^{2}$ A domestic music tourist is defined as 'someone who booked a ticket to a live music event in advance, and who travelled outside their home region to attend the event (or outside their home nation in the case of Scotland, Wales and N. Ireland)' (UK Music 2011: 4)
} 
study mean that direct comparison between festivals is inadvisable, even for the Edinburgh Festivals data.

Table 1: List of jazz festival economic impact assessments

\begin{tabular}{|c|c|}
\hline $\begin{array}{l}\text { Festival (date of } \\
\text { research) }\end{array}$ & Economic impact \\
\hline $\begin{array}{l}\text { St Lucia Jazz } \\
(1998)\end{array}$ & $\begin{array}{l}\text { Budget: US\$1.0m and visitor expenditure: US\$6.92m } \\
\text { (Nurse 2002: 129). }\end{array}$ \\
\hline $\begin{array}{l}\text { Air Jamaica Jazz } \\
\text { Festival (2000) }\end{array}$ & $\begin{array}{l}\text { 16,700 attendees (35\% overseas visitors); foreign } \\
\text { exchange impact estimated at US } \$ 550,000 \text {; budget was } \\
\text { US } \$ 750,000 \text {. The festival was used as a tool by the } \\
\text { sponsor to increase number foreign visitors and was } \\
\text { cancelled after four years once it was realized that such as } \\
\text { increase of tourists never transpired (Nurse } 2002: 131-2) \text {. }\end{array}$ \\
\hline Brecon Jazz (2000) & $\begin{array}{l}\text { Disaggregated economic impacts: Output: £907,000; Input: } \\
£ 217,000 ; \text { Employment (FTE): } 23 \text { person-years (Jones and } \\
\text { Munday } 2001: 10 \text { ). }\end{array}$ \\
\hline $\begin{array}{l}\text { Cheltenham Jazz } \\
\text { Festival (2002) }\end{array}$ & $\begin{array}{l}\text { 13,000 paid-for attendances; Music, Jazz, Literature and } \\
\text { Science festivals' total combined contribution to local } \\
\text { economy: c. } £ 3 m \text {. Inward cash sponsorship: } £ 600,000 \text {; } \\
\text { local authority expenditure: } £ 300,000 \text {; other grants: c. } \\
£ 120,000 \text { (Brookes and Landry } 2002: 2 ; 5) \text {. The Jazz } \\
\text { Festival generated more overnight stays than other } \\
\text { festivals (Ibid: } 9 \text { ). }\end{array}$ \\
\hline $\begin{array}{l}\text { North Sea Jazz } \\
\text { Festival (2002) }\end{array}$ & $\begin{array}{l}\text { c. } 70,000 \text { visitors in three days; c. } 20,000 \text { overnight stays; } \\
\text { over } € 9.6 \text { million in revenues; c. } 18,000 \text { people attended }\end{array}$ \\
\hline
\end{tabular}




\begin{tabular}{|c|c|}
\hline & $\begin{array}{l}\text { music events held prior to the festival; 15,000 people } \\
\text { visited free performances on outdoor stages and in cafés in } \\
\text { The Hague's city centre (Van Aalst and van Melik 2011: } \\
\text { 202). }\end{array}$ \\
\hline $\begin{array}{l}\text { Edinburgh } \\
\text { International Jazz } \\
\text { and Blues Festival } \\
\text { (2004) }\end{array}$ & $\begin{array}{l}\text { Estimated attendances of 75,000 (an increase from 49,581 } \\
\text { in 2002); £36.97 daily expenditure per person (incl. day } \\
\text { trips); Economic impact in Edinburgh: total output: £2.9m; } \\
\text { total input: £0.7m; } 53 \text { FTEs, and } 91 \text { press and broadcast } \\
\text { items. EIJBF had a much higher proportion of locals in its } \\
\text { audiences than the other summer Edinburgh festivals } \\
\text { (SQW Ltd and TNS Travel and Tourism 2005). }\end{array}$ \\
\hline $\begin{array}{l}\text { Monterey Jazz } \\
\text { Festival (2004) }\end{array}$ & $\begin{array}{l}25,000 \text { unique visitors purchased } 40,000 \text { admissions } \\
\text { tickets. Direct economic impact of } \$ 20 \mathrm{~m} \text { for greater } \\
\text { Monterey area. With multiplier effect (indirect or induced } \\
\text { spending) broader impact estimated at } \$ 30-40 \mathrm{~m} \text { (Monterey } \\
\text { Jazz Festival 2005). }\end{array}$ \\
\hline Brecon Jazz (2006) & $\begin{array}{l}\text { Generated between } £ 1.86 \mathrm{~m} \text { and } £ 2.2 \mathrm{~m} \text { of direct } \\
\text { expenditure in the town and the overall gross value was } \\
\text { estimated to be between } £ 2.9 \mathrm{~m} \text { and } £ 3.37 \mathrm{~m} \text { in the Welsh } \\
\text { economy; the festival created or safeguarded between } 63 \\
\text { and } 73 \text { FTE jobs (Lynn Jones Research 2006: 34). }\end{array}$ \\
\hline $\begin{array}{l}\text { Wangaratta Jazz } \\
\text { Festival (2006) }\end{array}$ & $\begin{array}{l}\text { Ticket sales in 2006: AUS } \$ 280,000 ; 30,000 \text { attendees; } 120 \\
\text { performance events. } 50 \% \text { of festival attendees spent more }\end{array}$ \\
\hline
\end{tabular}

\footnotetext{
3 It is worth noting that the AEA Consulting 'Thundering Hooves' report of 2006 also includes also data on international jazz festivals such as San Francisco and Montreal in comparison to Edinburgh's.
} 


\begin{tabular}{|c|c|}
\hline & $\begin{array}{l}\text { than } \$ 500 \text { at the festival (excluding festival passes and } \\
\text { tickets (Curtis } 2010: 107-9 \text { ). }\end{array}$ \\
\hline azz (2007) & $\begin{array}{l}\text { Total GVA activated in 2007: over } € 1.8 \mathrm{~m} \text { (in both the region } \\
\text { and the rest of the country); estimated impact of visitors' } \\
\text { expenditure on regional GVA: nearly } € 1.4 \mathrm{~m} \text {. Every euro of } \\
\text { public or institutional contribution produced about } € 2.65 \text { of } \\
\text { gross product, almost exclusively in the private sector of } \\
\text { the local economy (mostly hotels and restaurants) } \\
\text { (Bracalente et al 2011: 1249-1251). }\end{array}$ \\
\hline $\begin{array}{l}\text { Cape Town } \\
\text { International Jazz } \\
\text { Festival }^{4}(2009)\end{array}$ & $\begin{array}{l}\text { Visitor numbers: } 32,000 \text {. Total economic impact of foreign } \\
\text { visitors was R20.1m (spending mostly on tourist activities); } \\
\text { local visitors: R7.2m; visitors from the rest of South Africa: } \\
\text { R78.5m. Total annual impact: over R158m (Saayman and } \\
\text { Rossouw 2010). }\end{array}$ \\
\hline $\begin{array}{l}\text { Edinburgh Jazz } \\
\text { and Blues Festival }{ }^{5} \\
(2010)\end{array}$ & $\begin{array}{l}\text { Estimated paid-for attendances of 37,300; £41.10 daily } \\
\text { expenditure per person in Edinburgh; overall net economic } \\
\text { impact in Edinburgh: output } £ 1.29 \mathrm{~m} \text {, input £0.32m; } 26 \\
\text { FTEs; } 132 \text { articles. The Festival included a significant } \\
\text { proportion of Scottish artists (Chouguley, Naylor and } \\
\text { Rosemberg Montes 2011: 43). }\end{array}$ \\
\hline $\begin{array}{l}\text { Newport Jazz } \\
\text { Festival (2012) }\end{array}$ & $\begin{array}{l}\text { Expenditure by jazz festival-goers in Rhode Island } \\
\text { estimated at } \$ 1,939,681 \text {. For } 91 \% \text { of respondents, the } \\
\text { festival was their primary or sole reason for visiting }\end{array}$ \\
\hline
\end{tabular}

\footnotetext{
${ }^{4}$ cf Taylor and Slabbert's (2012) work on the Cape Town International Jazz Festival.
} 


\begin{tabular}{|l|l|}
\hline & $\begin{array}{l}\text { Newport. Reported incomes were above the national } \\
\text { average and 47.4\% of festival-goers have a graduate } \\
\text { degree (Advantage Marketing Information 2012). }\end{array}$ \\
\hline Festival (2013) & $\begin{array}{l}\text { Audience expenditure: £985,126; attendee expenditure: } \\
\text { funding: £145,595 (incl. local funding: £29,100; Arts Council } \\
\text { England: £90,146). Each £1 of public sector investment } \\
\text { generated £6.87 of new income into Manchester. Local } \\
\text { residents: } 31.3 \% \text {; local performers: } 21.5 \% \text { (Li and Chen } \\
2013: 3-4) .\end{array}$ \\
\hline Jazz à Vienne & $\begin{array}{l}\text { The Jazz à Vienne Festival brings together over } 60 \text { public } \\
\text { and private partners. } € 17 m \text { total economic impact } \\
\text { generated by the state-funded industrial \& commercial } \\
\text { establishment and audience expenditure. } € 15 m \text { economic } \\
\text { impact for 1€ of grant paid. 66\% all-round economic impact } \\
\text { benefitting the local area (Jazz à Vienne 2016: } 51) .\end{array}$ \\
\hline
\end{tabular}

While the table appears to show that jazz festivals have positive economic impacts overall, there is also an argument that jazz festivals are economically unsustainable without state funding, and have a negative economic impact by restricting funds which could be spent elsewhere (cf Hughes 2000: 170-1); research into this is currently scant, however. Conversely, a review of jazz in England in 1995 presented arts organisation Serious, producer of the EFG London Jazz Festival, as a model of what can be done 'with a small but significant level of public funding and a great deal of energy' (Arts Council of England 1995: 28). 


\section{Socio-political impact}

On the whole it seems that only Jazz and Reggae music possess the ability to transcend racial and cultural barriers and to draw people together, regardless of circumstances (Pietersen 1999: 69).

The other thing I think which is really good and progressive is the number of young women coming into jazz.... Women have a much greater part to play in the moulding of jazz and the music generally, which is a tremendous development (71-year-old male EFG London Jazz Festival-goer, 2015).

Jazz festivals have been sites for social and political debate, sometimes action (McKay 2003, 2005, 2015). Jazz is a music of black origin and has played a significant role in the fight for civil rights; issues of race, therefore, are never far from the surface. At the Grahamstown Festival in the new South Africa of 1994, for example, it was only the jazz and reggae concerts that saw mixed black and white audiences (Pietersen 1999: 68-9). As UNESCO's international jazz day recognises or claims, the cross-cultural, democratic nature of jazz lends itself to a 'diplomatic role of uniting people in all corners of the globe' (International Jazz Day 2016). As an indication of the collaborative nature of jazz organizations, in Europe, jazz festivals are connected through the Europe Jazz Network, set up in 1987 to connect jazz promoters across Europe to share ideas about musicians and live promotion; members today use the network to drive European projects and develop collaborations in organising tours and concerts (Goh 2012).

However, other commentators question jazz's role as a marginal oppositional force as it continues to be a minority taste and hence somewhat circumscribes the "utopian and far-reaching claims' made about jazz's ability to transform society (Stanbridge 
2008: 10). Indeed, with its American origins, jazz has been accused of being an 'early soundtrack of the hegemon' whose global spread coincided with hegemonic authority throughout the twentieth-century (McKay 2005: 11). More contextually specific socio-political issues can be seen in places with a particular history of racial separatism, such as New Orleans (Gotham 2005; Regis and Walton 2008; Porter 2009) and Grahamstown, South Africa (Pietersen 1999). Commentators have suggested that the New Orleans Jazz and Heritage Festival, for example, has been a 'battlefield of contention' (Gotham 2005: 236) for cultural issues around race and gender for a number of years, exacerbated and accentuated by 2005 's devastating Hurricane Katrina (Meadows 2014). The festival's tourist appeal can be seen as a vital income generator or as a threat to local culture (Gotham 2005), for instance; while for some, the festival exploits and further marginalises black culture and for others it celebrates and foregrounds it (Regis and Walton 2008). Separatist women's jazz festivals such as those in Sydney, Washington and Melbourne, ensure that women jazz composers and performers are promoted and celebrated and are important sites of artists' creative and career development (Denson 2014), but their existence points to a long-running gender imbalance within the sector. The frivolity of festivals, then, sometimes masks deeper socio-political issues around race, class and gender (for example, see Gotham 2005; Regev 2011; Wilks 2013).

\section{Temporal impact and intensification and transformation of experience}

I know [the festival's] always in November, so I know that's always when it's going to be, so you sort of plan your life around it a little bit (60-year-old female EFG London Jazz Festival-goer, 2015). 
So much melting with space and everything and just forgetting the environment for a moment, and it gives you really the opportunity just for a moment to break out. This is what I specifically enjoy about the festival and that's what makes it different to individual concerts, because individual concerts usually have this idea, like ... there's too much concentration on it (50-year-old male EFG London Jazz Festival-goer, 2015).

Jazz festivals, as with many festivals, are often cyclical and annual/biennial (Van Aalst and van Melik 2011: 196), and occur at particular periods within the annual calendar; they can therefore become a pivot around which the rest of the year is planned (Packer and Ballantyne 2010). Furthermore, jazz festivals allow for intense production and consumption of music over a relatively short period of time in a particular geographical place. However, while there is some research about the jazz performer-audience relationship (Deschênes 2000; Burland and Pitts 2010; Brand et al 2012; Pitts and Burland 2013), and on the demographics of jazz festival audiences (Oakes 2003, 2010), there is little extant work on the impact of jazz festivals on musicians and festival staff (permanent, casual and voluntary) (cf Goh 2004). Also, jazz festivals have been sites for transformative - even spiritual - experiences for their participants (Regis and Walton 2008; Walton 2012). Motivation to attend festivals in general is either to escape everyday life and/or to seek new experiences (Crompton and McKay 1997) while at the more extreme end of the scale, jazz festivals have caused people to change career or lifestyle, to move to be closer to a festival site, or to behave differently towards others (Walton 2012).

Jazz festivals have the ability to transform a town or city once a year as the interactions of the jazz festival - the musicians, the people - allow 'musicking' (Small 
1998) as a ritual that reflects the ideas of 'ought-to-be-relationships in the world' for its participants (Dvinge 2015: 195) and become a time in which 'joy takes root annually' (lbid.: 185). Festivals will often have a visually transformative impact on the immediate locale in which it takes place through the use of mobile spaces such as outdoor stages (Oakes and Warnaby 2011), or devices such as banners or bunting to tie the festival together (Eales 2013). In addition, festivals can create new meaning for participants in a familiar place by using venues not usually used for music/arts or they may even develop new spaces for jazz and other music (BOP Consulting 2013: 49; Eales 2013).

Jazz festivals are sites for renewing old acquaintances and making new ones, and for being with like-minded listeners (Pitts and Burland 2013) - one London interviewee said that the festival was 'like an extended family' of musicians and fans. Indeed, many of the studies of motivation in the event management and tourism studies literature found that major motivations for festival attendance in general were socialization and family togetherness (regarding jazz festivals in particular, see Saleh and Ryan 1993; Formica and Uysal 1996; Thrane 2002; Taylor and Slabbert 2012; Pitts and Burland 2013; Wiliams and Saayman 2013; Kemp and White 2013; and Calder, Isaac and Malthouse 2013.). ${ }^{6}$ However, the potential for socialization depends on the venue and the place: larger festivals, for instance, often lack opportunities for socialization because of their size and spread. Festival attendance develops participants' social capital by providing the community with opportunities for social cohesiveness, accessing and developing community resources, and by providing a focus for celebration (Arcodia and Whitford 2006). Festival producers in

\footnotetext{
${ }^{6}$ See Abreu-Novais and Arcodia (2013) for a useful review of motivations in relation to music festivals more broadly.
} 
particular need to draw on their social capital and networks in order to overcome challenges such as problems with artists or venues (Webster 2011).

\section{Creative impact - music and musicians}

That [festival] gig for us was really great ... Lots of people there were industry, lots of people were reviewers ... And we're in talks with a couple of people who were there about festivals in the future ... so it's possible other gigs may come out of it as well (Bex Burch, band leader, Vula Viel, 2016).

Jazz festival producers are cultural importers and cultural intermediaries (Keogh 2014). Headliners for major international festivals are often high status American artists; indeed, jazz festivals often book international artists and include the word 'international' in the event title in an effort to increase the status and ticket sales of the festival. Jazz festivals are also springboards for artist development and many larger festivals have talent development and training programmes for up-andcoming-artists. ${ }^{7}$ Jazz musicians use festivals as a means of developing their networks and for developing musical ideas and practices. However, while some research exists on the development of jazz musicians (see Umney and Kretsos 2014), there is little yet about the specific impacts of festivals on their career development, or even on the important roles of festivals in commissioning new work (cf sam and the University of Brighton 2008). Jazz festivals have also been sites for the celebration of jazz history (for example, see Regis and Walton 2008) and the construction of jazz heritage (Dancer 2009).

\footnotetext{
${ }^{7}$ For example, Serious Music's Take Five programme or the Montreux Jazz Academy.
} 
Jazz festivals are also sites for genre development and opportunities for combining previously disparate artforms. So-called 'cultural dating' (Gladstone 2015) involves combining two or more artists who have not previously worked together - it is often undertaken for artistic objectives or for audience development purposes and may be instigated by the artists themselves or at the suggestion of the festival director. In this way, whilst jazz festivals sometimes have limited transformative effects on their immediate environment, they can impact on the development of the art form. However, there is little research as yet about the creative role of the jazz festival producer and, more broadly, the creative impact of jazz festivals.

\section{Discovery and audience development}

What I love about festivals generally is curated events - you get the sense of things being chosen rather than just, like, not so much a no-man's-land, but there's everything out there and you really have to kind of, know ... I just kind of read a short blurb and you're like, 'Yeah, that sounds interesting; l'll go' (28year-old male EFG London Jazz Festival-goer, 2015).

Jazz festivals are sites for learning and personal development, for musicians, audiences, and crew (including volunteers). Assessment of volunteer numbers is one measurement of social impact (for example, see BOP Consulting 2013), as festivals provide volunteers with learning and development opportunities that can help with employment prospects (Jones and Munday 2001: 11) as well as opportunities for social interaction, social togetherness and development of social capital (Arcodia and Whitford 2006; Vestrum 2014; Ring 2014). In addition, festivals have been identified as 'key tools' for developing new audiences for jazz (Jazz Development Trust and Morris Hargreaves McIntyre 2001: 67). Jazz festival producers walk a fine 
line between innovation and continuity, however, in their efforts to both maintain existing audiences and develop new ones (Vigneault, Chassé and Lapierre 2006; Medbøe 2013: 8).

\section{Place-making}

The relationship between the festival and the city is really intimate. It can never be separate. It's the Kongsburg Jazz Festival, not the Wherever Jazz Festival (Martin Revheim, then director of Kongsburg Jazz Festival, Norway, cited in Vigneault, Chassé and Lapierre 2006).

Jazz festivals have become 'ubiquitous' within tourism and place marketing campaigns (Gibson and Connell 2005: 223). Jazz festivals often contribute to a positive image of a locale, both internally to its residents and externally to visitors, and hence attract people to live in the place and tourists to visit (van Limburg 1998; Lemmetyinen, Go, and Luonila 2013). The festival, including the jazz event, helps to foster a sense of belonging among its participants and provide employment and a proud sense of place for its locals (Curtis 2010) - it isn't just the 'Wherever Festival' (although here the argument of MacLeod 2006 on 'placelessness', however, might resonate with the global, 'ubiquitous' form of jazz).

The significance of festivals to the identity of Edinburgh can be seen in the two Thundering Hooves reports, ${ }^{8}$ curiously insecure yet self-assured documents which make recommendations as to how best the Scottish city of Edinburgh should support its festivals (including the Jazz and Blues Festival) to maintain its edge as the 'world's premier festival city' whilst at the same time recognising that other cities may

\footnotetext{
8 'Thundering hooves' refers to the prediction of the imagined sound of horses - other festival cities galloping past Edinburgh if the city's agencies and institutions were complacent in supporting and developing the city's festivals.
} 
also have valid claim for the same title (AEA Consulting 2006: 11; BOP Consulting 2015). However, an influx of visitors is not unproblematic and can reveal deepseated tensions: local authorities may use the 'imagined tourist' gaze as 'judgmental Other' to sanitize parts of a town or city deemed unsightly before a festival event (Atkinson and Laurier 1998: 205; cf Porter 2009).

Jazz festivals play a part in the (economic and physical) regeneration of a city or region (Eales 2013) or enable it to expand its political, economic, environmental and social influence (Lemmetyinen, Go, and Luonila 2013). Small countries such as Israel put on international festivals like the Red Sea Jazz Festival 'in order to claim recognition for the equal status of local culture in the global frontiers of cultural and artistic innovation' by interweaving their own culture with those of other countries (Regev 2011; also see AEA Consulting 2006), or even using the perceived authentic 'place-image' of the 'cradle of jazz' - New Orleans - to re-imagine their own cities (Darroch 2003). Jazz festivals are often sites for showcasing local talent and for creating a platform for exporting musicians abroad (Washburne 2010; Payne and Jeanes 2010), particularly at so-called 'field configuring events' (Leenders, Go and Bhansing 2015: 758) - those which draw together key industry figures - like the London and North Sea jazz festivals.

\section{The mediation of jazz festivals}

The impact of festivals is not only felt within the temporal and geographical location of their host city or town: festivals continue to live on via new social connections, recordings and ensembles which are born out of them (Curtis 2010: 114). The mediation of festival via 'traditional' and new media is another pathway to impact (Wall and Dubber 2010), and the use of digital and social media for festival 
promotion and the construction of jazz festival identity has been explored (Sykes 2014). Media coverage and the estimated valuation of such coverage is a feature of economic impact assessments of both Cheltenham (Brookes and Landry 2002: 5-6) and Edinburgh (SQW Ltd and TNS Travel and Tourism 2005: 66-9; Chouguley, Naylor and Rosemberg Montes 2011: 40-6).

The (under-)representation of jazz in British media is an on-going issue: a report from 2009 into BBC coverage of jazz claimed that the BBC was 'not, in the eyes of many engaged in the British jazz economy, supporting British jazz to the extent it could, and many feel should' (Nicholson, Kendon and Hodgkins 2009: 12). However, it was felt that more jazz on the BBC would promote the artform to both British and European markets. The EFG London Jazz Festival partnered with BBC Music, BBC Radio Scotland, and Radio 1, 2, 3 and 6 Music in 2015, which meant that, alongside a dedicated temporary 'pop up station', the event could be 'cross-trailed' across radio and website platforms, leading one London Jazz Festival-goer to remark that 'it just did feel like it was everywhere this year'.

The history of jazz festival mediation is also of interest; the 1960 Beaulieu Jazz Festival BBC live outside broadcast, for instance, was shut down as a result of crowd trouble during the so-called Battle of Beaulieu (McKay 2004). The 1959 film of the Newport Jazz Festival, as another example, Jazz on a Summer's Day created a 'blueprint for all subsequent representations of pop festival films' (Goodall 2015: 378), and television documentaries about the music reconstruct and re-present it to new generations (Wall and Long 2009). 


\section{Environmental impact}

It was as if two events were taking place simultaneously—an all day pub crawl and a jazz festival (Brecon Jazz attendee, cited in Lynn Jones Research 2006: 65).9

Though their environmental impacts are usually less significant than for some other forms of outdoor popular music festival, jazz festivals temporarily increase the population of a locale thereby putting pressure on local infrastructures such as accommodation, transport, even policing (McKay 2005). In addition, festivals may have environmental impacts such as increased noise (Oakes and Warnaby 2011) or anti-social behaviour (Lynn Jones Research 2006), including increased crime levels, excessive drinking, and litter, or injustice/inconvenience such as noise, traffic congestion and parking, and overcrowding (Deery and Jago 2010). City-based events tend to receive a much higher percentage of their audience by public transport, so the impact of audience travel on their carbon footprint is comparatively less (Powerful Thinking 2014: 25). Other environmental impacts are less localized: international jazz festivals put on touring artists, the logistics of which are inherently resource-intensive and have a large carbon footprint, particularly when also factoring in audience travel (Jenkins et al 2011). ${ }^{10}$ To attempt to mitigate the environmental impact of jazz festivals, the Europe Jazz Network is working with the creative industries sustainability advocate, Julie's Bicycle, to encourage its members to be as environmentally sustainable as possible (Europe Jazz Network).

\section{The impact of academic research on jazz festivals}

\footnotetext{
${ }^{9}$ cf Jones and Munday 2001: 11

${ }^{10}$ Albeit focused on outdoor summer music festivals rather than urban jazz festivals, the estimated total UK festival industry emissions (excluding travel) is 19,778 tonnes of $\mathrm{CO}_{2}$ per year (Powerful Thinking 2015: 2).
} 
I really admire the work that has been done, the research into jazz: documenting the history of the music, audience research, and then just looking at the history and the influence of certain musicians ... As part of [another] AHRC project, the idea of looking at some of the black British performers, that planted an idea, and we got back to programming Denys Baptiste and his 'Let Freedom Ring' suite, which was originally commissioned by Cheltenham Jazz Festival ... so the idea of doing what is a follow-up ... that came from a discussion with George McKay (Tony Dudley-Evans, programme advisor of Cheltenham Jazz Festival; McKay 2014).

Drawing on the findings above, arts and humanities research (including practicebased work) has had some impact on jazz festivals, often by way of providing evidence and theoretical underpinnings for organizations to make the case to funders and sponsors for further investment. The Manchester Jazz Festival, for example, used its economic impact assessment - carried out by Master's students studying at Manchester University's Business School in 2013 - to make a strong case to sponsors. As another example, the 'Rhythm Changes' project (http://www.rhythmchanges.net) brings together jazz researchers across Europe and has used theoretical and practice-led research methods to answer questions about jazz in a changing Europe; it has contributed to new programming directions and enabled Serious, producers of the EFG London Jazz Festival, to secure additional funding (REF 2014 Impact Case Studies).

Furthermore, jazz festivals can be a site of research collaboration and debate (although this appears to be the exception rather than the rule); recent examples include the EFG London Jazz Festival (collaborative research partner for The Impact of Festivals project), Cheltenham Jazz Festival (a public engagement partner with 
the AHRC 2013-15 for the dissemination of funded research on jazz), and the longrunning Colloquium and associated online journal (Critical Studies in Improvisation) at the Guelph Jazz Festival in Canada (Stanbridge 2008: 7). In further activity, Professors George McKay (2014) and Tony Whyton (2015) have both been Professor-in-Residence at the EFG London Jazz Festival and have overseen and chaired a number of public talks and debates about jazz and festivals; Dr Emma Webster was AHRC-funded researcher-in-residence with the EFG London Jazz Festival in 2015-16; for 2016, the Edinburgh Jazz and Blues Festival had researchers-in-residence from Napier University, and Tony Whyton was the researcher-in-residence at the Festa do Jazz in Portugal.

The Research Excellence Framework exercise is one means of evaluating research impact: searching for 'festival' on the REF 2014 case studies website returns 732 results while 'jazz festival' returns eight. The Wellcome Trust has also carried out research into public engagement and found that $30 \%$ of researchers had engaged in a festival/fair (science, literary, arts) in 2015 (Hamlyn et al 2015: 17). The National Co-coordinating Centre for Public Engagement has produced a practical guide called University Engagement in Festivals (Buckley et al), although it appears that specific work around the impact of research on (jazz) festivals is currently lacking.

\section{Recommendations for future research}

Based on this review of the academic and 'grey'/cultural policy literature, the following are recommendations for further study:-

- An authoritative history of (jazz) music festivals (in Britain ${ }^{11}$ );

\footnotetext{
${ }^{11}$ Extant work within this field includes: McKay 2003, 2005, 2015; Rhythm Changes 2013a; Knowles 2011; and Frith et al 2013.
} 
- Further research on the impact of festivals on musicians, for example on their career paths and the economic and social impact of festivals, and the role of festivals in commissioning new work;

- Development of an interdisciplinary, mixed methods approach to measure economic, social and cultural impacts of festivals, including qualitative analysis of stakeholder interviews; ${ }^{12}$

- New theorizations of festival and carnival to take into account the improvisatory spirit and transatlantic origins of jazz - how, if at all, can jazz festivals contribute to the re-theorization of carnivalesque?

- Much greater research into the significant potential of the negative impacts of jazz festivals in order to more accurately reflect the net impact of festivals. For example: privileging of certain genres over others, questions of economic sustainability and market failure, the emphasis on prestige festivals at the expense of year-round community-based schemes, ${ }^{13}$ gender imbalances, environmental impacts, antisocial behaviour and costs of policing;

- Further research into the impact of festivals on black culture from artist and audience perspectives;

- Further research into the mediation of jazz and its impactful relationship with festivals;

- Analysis of networks between jazz festivals and artists' touring schedules to understand competition and collaboration between festivals, including mapping of how festivals 'share' programmes and mapping of artists' tours;

- Assessment as to the value/efficacy of free events as part of jazz festivals and the relationship between free and paid events in terms of audience development and commercial drivers ${ }^{14}$;

- Research into the creative role of the producer;

- Further research into the impact of research on (jazz) festivals;

\footnotetext{
${ }^{12}$ cf Mann Weaver Drew \& De Montfort University (2003) for one of an example of impact assessment which includes qualitative and quantitative research, albeit written before the inclusion of environmental impact. Chouguley, Naylor and Rosemberg Montes (2011) claim to offer a '360 degree' approach to assessing impact that considers social, cultural, environmental and media aspects, in addition to the economic effects of Edinburgh's festivals but this is quantitative rather than qualitative, although they do note that qualitative audience research is very resource intensive.

${ }^{13}$ cf Hughes 2000: 170-1.

${ }^{14} \mathrm{cf}$ Warwick Commission report into the future of cultural value which found that free museum attendance has meant a decrease in lower socio-economic group attendance (Neelands et al 2015: 34).
} 
- Co-produced research between jazz festival organizations and academic researchers in order to explore issues of benefit and relevance to festivals. 


\section{Bibliography}

To accompany the article, a 100 -entry 40,000 word annotated bibliography has also been produced, which is accessible online via the project website (https://impactoffestivals.wordpress.com/project-outputs/).

Abreu-Novais, Margarida and Charles Arcodia. 2013. 'Music festival motivators for attendance: developing an agenda for research'. International Journal of Event Management Research 8(1): 34-48.

Advantage Marketing Information. 2012. Newport Festivals Foundation - An Economic Impact Study. North Kingstown, Rhode Island: Advantage Marketing Information. Accessed 05-Jul-16. http://www.dem.ri.gov/folkjazzeis.pdf.

AEA Consulting. 2006. Thundering Hooves: Maintaining the Global Competitive Edge of Edinburgh's Festivals. London: AEA Consulting. Accessed 17-Dec-15. http://www.scottisharts.org.uk/DownloadPublication.aspx?pub=11279.

Arcodia, Charles and Michelle Whitford. 2006. 'Festival attendance and the development of social capital'. Journal of Convention and Event Tourism 8(2): $1-18$.

Arts Council of England. 1995. Review of Jazz in England. London: Arts Council of England.

Atkinson, David and Eric Laurier. 1998. 'A sanitised city: social exclusion at Bristol's 1996 international festival of the sea'. Geoforum 29(2): 199-206.

Bakhtin, Mikhail. 1968. Rabelais and his World. Trans. by Helene Iswolsky. Cambridge: MIT Press.

Behr, Adam, Matt Brennan, Martin Cloonan, Simon Frith \& Emma Webster. 2016. 'Live Concert Performance: An Ecological Approach'. Rock Music Studies: The Live Concert Experience 3(1): 5-23.

Bennett, Andy, Jodie Taylor and Ian Woodward, eds. 2014. The Festivalization of Culture. Farnham: Ashgate.

BOP Consulting. 2013. The Economic, Social and Cultural Impact of the City Arts and Culture Cluster. London: City of London Corporation. Accessed 17-Dec-15. https://www.cityoflondon.gov.uk/business/economic-research-andinformation/research-publications/Documents/research-2013/Economic-socialcultural-impact-of-the-city-arts-and-culture-clusture-ForWeb.pdf.

BOP Consulting. 2015. Edinburgh Festivals: Thundering Hooves 2.0: A Ten Year Strategy to Sustain the Success of Edinburgh's Festivals. London: BOP Consulting. Accessed 17-Dec-15. 
http://www.edinburghfestivalcity.com/assets/000/000/823/TH 20 full report original.pdf?1432048731.

Bracalente, Bruno, Cecilia Chirieleison, Massimo Cossignani, Luca Ferrucci, Marina Gigliotti and M. Giovanna Ranalli. 2011. 'The economic impact of cultural events: the Umbria Jazz music festival'. Tourism Economics 17(6): 1235-1255.

Brand, Gail, John Sloboda, Ben Saul, and Martin Hathaway. 2012. 'The reciprocal relationship between jazz musicians and audiences in live performances'. Psychology of Music 40(5): 634-651.

Brookes, Fred and Charles Landry. 2002. Good Times: The Economic Impact of Cheltenham's Festivals. n/a: Unpublished - obtained directly from authors.

Buckley, Nicola, Joanna McPhee and Eric Jensen. 2011. University Engagement in Festivals: Top Tips and Case Studies. NCCPE. Accessed 26-Jan-16. http://www.publicengagement.ac.uk/sites/default/files/Festivals\%20Top\%20Tip s\%20and\%20Case\%20Studies 0.pdf.

Burland, Karen and Stephanie E. Pitts. 2010. 'Understanding jazz audiences: listening and learning at the Edinburgh Jazz and Blues Festival'. Journal of New Music Research 39(2): 125-134.

Calder, Bobby, Mathew Isaac, and Edward Malthouse. 2013. Taking the Customer's Point-of-View: Engagement or Satisfaction? Marketing Science Institute.

Accessed 11-Jan-16. http://www.msi.org/reports/taking-the-customers-point-ofview-engagement-or-satisfaction-1/.

Carnwath, John D. and Alan S. Brown. 2014. Understanding the Value and Impacts of Cultural Experiences. Arts Council England. Accessed 08-Aug-16. http://www.artscouncil.org.uk/sites/default/files/downloadfile/Understanding the Value and Impacts of Cultural Experiences.pdf.

Chouguley, Ulrike, Richard Naylor, and Cristina Rosemberg Montes. 2011. Edinburgh Festivals Impact Study. London: BOP Consulting. Accessed 08-Aug15. http://www.etag.org.uk/wp-content/uploads/2013/11/110520-edinburghfestivals-finaloverallreport-bop final.pdf.

Crompton, John and Stacey McKay. 1997. 'Motives of visitors attending festival events'. Annals of Tourism Research 24(2): 425-439.

Curtis, Rebecca Anne. 2010. 'Australia's capital of jazz? The (re)creation of place, music and community at the Wangaratta Jazz Festival'. Australian Geographer 41(1): 101-116.

Dancer, Thomas. 2009. South African Jazz Heritage at the Standard Bank Joy of Jazz Festival in Newtown, Johannesburg (Master's diss, University of the Witwatersrand, Johannesburg). 
Darroch, Michael. 2003. 'New Orleans in Montréal: the cradle of jazz in the city of festivals'. Géocarrefour 78(2): 129-137.

Deery, Margaret and Leo Jago. 2010. 'Social impacts of events and the role of antisocial behaviour'. International Journal of Event and Festival Management 1(1): 8-28.

Denson, Louise. 2014. 'Perspectives on the Melbourne International Women's Jazz Festival'. Jazz Research Journal 8(1-2): 163-181.

Deschênes, Bruno. 2000. 'The Montreal International Jazz Festival'. Popular Music 19(2): 253-255.

Doctor, Jenny, David Wright, and Nicholas Kenyon. 2007. The Proms: A New History. London: Thames and Hudson.

Dvinge, Anne. 2015. 'Musicking in motor city: Reconfiguring urban space at the Detroit Jazz Festival'. In The Pop Festival, ed. George McKay, 183-197. London: Bloomsbury.

Eales, Alison. 2013. "They've really gone to town with all that bunting': the influence and (in)visibility of Glasgow's Jazz Festival'. Jazz Research Journal 7(1): 9-21.

Europe Jazz Network. 'Julie's Bicycle and Europe Jazz Network at WOMEX'. Accessed 25-Jan-16. http://www.europejazz.net/take-green-train.

Formica, Sandro and Muzaffer Uysal. 1996. 'A market segmentation of festival visitors: Umbria Jazz Festival in Italy'. Festival Management and Event Tourism 3: 175-182.

Frith, Simon. 2007. 'Live music matters'. Scottish Music Review 1(1): 1-17.

Frith, Simon, Matt Brennan, Martin Cloonan and Emma Webster. 2013. The History of Live Music in Britain, I: 1950-1967: From Dance Hall to the 100 Club. Farnham: Ashgate Publishing Ltd.

Getz, Donald. 2008. 'Event tourism: definition, evolution, and research'. Tourism Management 29: 403-428.

Getz, Donald. 2010. 'The nature and scope of festival studies'. International Journal of Event Management Research 5(1): 1-47.

Gibson, Chris and John Connell. 2005. Music and Tourism: On the Road Again. Clevedon: Channel View Publications.

Gladstone, Emma. 2015. The Role of the (Jazz) Festival' (panel discussion at the EJG London Jazz Festival, Barbican, London, $22^{\text {nd }}$ November). 
Goh, Fiona. 2004. Irish Festivals, 'Irish Life'. Ballinasloe, Co. Galway, Ireland: AOIFE.

Goh, Fiona. 2012. Strength in Numbers: A Study of the Europe Jazz Network. Europe Jazz Network. Accessed 18-Dec-15. http:/heranet.info/system/files/ejn report webres final 0.pdf.

Goodall, Mark. 2015. 'Out of sight: the mediation of a music festival'. In The Pop Festival, ed. George McKay, 33-48. London: Bloomsbury.

Gotham, Kevin Fox. 2005. 'Theorizing urban spectacles: festivals, tourism and the transformation of urban space'. City: Analysis of Urban Trends, Culture, Theory, Policy, Action 9(2): 225-246.

Hamlyn, Becky, Martin Shanahan, Hannah Lewis, Ellen O'Donoghue and Tim Hanson. 2015. Factors Affecting Public Engagement by Researchers: A Study on Behalf of a Consortium of UK Public Research Funders. London: TNS BMRB. Accessed 08-Aug-16. https://wellcome.ac.uk/sites/default/files/wtp060033 0.pdf.

Hughes, Howard. 2000. Arts, Entertainment and Tourism. Oxford: ButterworthHeinemann.

Ilczuk, Dorota and Magdalena Kulikowska. 2007. Festival jungle, policy desert? Festival policies of public authorities in Europe: CIRCLE, 2007. Accessed 08Aug-2016.

http://www.kulturdokumentation.org/download/Festival policies draft 2007101 4.pdf.

International Jazz Day. 'About'. Accessed 25-Jan-16. http://jazzday.com/about/.

Jazz à Vienne (2016). Press release. Jazz à Vienne. Accessed 06-Jul-16. http://newsroom.onlylyon.com/files/e4a81d22/dossier de presse jazzavienne en 160422 bd.pdf.

Jazz Development Trust and Morris Hargreaves McIntyre. 2001. How to Develop Audiences for Jazz. Arts Council England. Accessed 08-Aug-15. http://www.creativenorthyorkshire.co.uk/documents/DevAudJazz1.pdf.

Jazzfests.net. 2015. 'Jazz festivals in the United Kingdom.' Accessed 26-Jan-16. http://jazzfests.net/countries/?country=uk.

Jenkins, lan, Ruth Rios-Morales, and Ralph Cervera. 2011. 'Music festivals: sustainable futures? The case study of two Swiss events'. In 4th Annual EuroMed Conference of the EuroMed Academy of Business: 872-882.

Jones, Calvin and Max Munday. 2001.'Tourism and local economic development: three case studies' (paper presented at the European Regional Science 
Association 41st Annual Meeting 'European Regional Development Issues in the New Millennium and their Impact on Economic Policy', Zagreb, Chamber of Economy, Croatia, August).

Jones, Calvin and Max Munday. 2004. 'Evaluating the economic benefits from tourism spending through input-output frameworks: issues and cases'. Local Economy 19(2): 117-133.

Kemp, Elyria and Michael G. White. 2013. 'Embracing jazz: exploring audience participation in jazz music in its birthplace'. International Journal of Arts Management 16(1): 35-48.

Keogh, Brent. 2014. "A tale of five festivals": Exploring the cultural intermediary function of Australian jazz festivals'. Jazz Research Journal 8(1-2): 182-201.

Knowles, Nod. 2011. 'Reflections on the festival business' (paper presented at the Live Music Exchange conference, Edinburgh).

Kronenburg, Robert. 2011. 'Typological trends in contemporary popular music performance venues'. Arts Marketing: An International Journal 1(2): 136-144.

Leenders, Mark A. A. M., Frank M. Go and Pawan V. Bhansing. 2015. 'The importance of the location in hosting a festival: a mapping approach'. Journal of Hospitality Marketing and Management 24(7): 754-769.

Lemmetyinen, Arja, Frank Go and Mervi Luonila. 2013. 'The relevance of cultural production - Pori Jazz - in boosting place brand equity'. Place Branding and Public Diplomacy 9(3): 164-181.

$\mathrm{Li}$, Jiayi and Zhouji Chen. Economic Impact Assessment for Manchester Jazz Festival 2013. University of Manchester, 2013. Accessed 07-Jan-16. Via email from Manchester Jazz Festival.

Lyck, Lisa, Phil Long, and Allan Xenius Grige. 2012. Tourism, Festivals and Cultural Events in Times of Crisis. Frederiksberg: Copenhagen Business School Press.

Lynn Jones Research. 2006. HSBC Brecon Jazz Festival 2006: Final Report. Lynn Jones Research. Accessed 13-Jan-16. Via email from LJR.

MacLeod, Nicola E. 2006. 'The placeless festival: identity and place in the postmodern festival'. In Festivals, Tourism and Social Change: Remaking Worlds, eds David Picard and Mike Robinson, 222-237. Clevedon: Channel View Publications.

Mann Weaver Drew and De Montfort University. 2003. The Economic Impact of the Notting Hill Carnival. London Development Agency. Accessed 17-Dec-15. http://tfconsultancy.co.uk/reports/nottinghillcarnival.pdf. 
McKay, George. 2003. "'Just a closer walk with thee”: New Orleans-style jazz and the Campaign for Nuclear Disarmament in 1950s Britain'. Popular Music 22(3): 261-281.

McKay, George. 2004. "Unsafe things like youth and jazz": Beaulieu Jazz Festivals (1956-61), and the origins of pop festival culture in Britain'. In Andy Bennett (ed.), Remembering Woodstock (Aldershot: Ashgate), 90-110.

McKay, George. 2005. Circular Breathing: The Cultural Politics of Jazz in Britain. Durham: Duke University Press,

McKay, George. 2014. Producer. Carnivalising the Creative Economy: AHRC-funded Research on and with British Jazz Festivals. Film. https://www.youtube.com/watch?v=Lwo7yfG1UGQ.

McKay, George. 2015. "The pose ... is a stance": popular music and the cultural politics of festival in 1950s Britain'. In The Pop Festival, ed. George McKay, 1331. London: Bloomsbury.

Meadows, Ruthie. 2014. '“Jockomo Fee Na Nay!” Afro-Caribbean and Afro-Creole sensorialities and the festivalisation of New Orleans's musical tourism'. In Sun, Sea, and Sound: Music and Tourism in the Circum-Caribbean, eds. Timothy Rommen and Daniel T. Neely, 238-266. Oxford: Oxford University Press.

Medbøe, Haftor. 2013. The promoter as cultural conduit: between jazz and a hard place. Jazz Talks 1st University of Aveiro jazz conference, November 2013, Aveiro PT.

Monterey Jazz Festival. 2005. Press release, 24 August. n/a: Unpublished - obtained directly from authors.

Neelands, Jonothan, Eleonora Belfiore, Catriona Firth, Natalie Hart, Liese Perrin, Susan Brock, Dominic Holdaway, Jane Woddis. 2015. Enriching Britain: Culture, Creativity and Growth: Warwick Commission on the Future of Cultural Value. Accessed 04-Jan-16. http://www2.warwick.ac.uk/research/warwickcommission/futureculture/finalrepo rt/warwick commission report 2015.pdf.

Nicholson, Stuart, Emma Kendon, Chris Hodgkins. 2009. The BBC: Public Sector Radio, Jazz Policy and Structure in the Digital Age. Jazz Services. Accessed 08-Aug-16. http://www.chrishodgkins.co.uk/wpcontent/uploads/2015/01/JazzonBBCreport.pdf.

Nurse, Keith. 2002. 'Bringing culture into tourism: festival tourism and Reggae Sunsplash in Jamaica'. Social and Economic Studies 51(1): 127-143.

Oakes, Steve. 2003. Demographic and sponsorship considerations for jazz and classical music festivals. The Service Industries Journal 23(3): 165-178. 
Oakes, Steve. 2010. Profiling the jazz festival audience. International Journal of Event and Festival Management 1(1): 110-119.

Oakes, Steve and Gary Warnaby. 2011. 'Conceptualizing the management and consumption of live music in urban space'. Marketing Theory 11(4): 405-418.

Packer, Jan and Julie Ballantyne. 2010. 'The impact of music festival attendance on young people's psychological and social well-being'. Psychology of Music 39(2): 164-181.

Payne, Julia and Adam Jeanes. 2010. 'Mapping' and 'Gapping' the Current International Music Infrastructure in England. London: Arts Council England. Accessed 08-Aug-16.

http://www.creativenorthyorkshire.com/documents/music mapping gapping.pdf

Pietersen, Dudley. 1999. 'Patterns of change; audience, attendance, and music at the 1994 Grahamstown festival'. Contemporary Theatre Review 9(2): 61-70.

Pitts, Stephanie E. and Karen Burland. 2013. 'Listening to live jazz: an individual or social act?' Arts Marketing: An International Journal 3(1): 7-20.

Porter, Eric. 2009. 'Jazz and revival'. American Quarterly: In the Wake of Katrina: New Paradigms and Social Visions 61(3): 593-613.

Powerful Thinking. 2015. The Show Must Go On. Powerful Thinking. Accessed 25Jan-16. http://www.powerful-thinking.org.uk/site/wpcontent/uploads/TheShowMustGoOnReport LR.pdf.

REF 2014 Impact Case Studies. 'Rhythm Changes: Jazz Cultures and European Identities-promoting the cultural value of jazz in Europe'. Accessed 25-Jan-16. http://impact.ref.ac.uk/CaseStudies/CaseStudy.aspx?ld=21729.

Regev, Motti. 2011. 'International festivals in a small country: rites of recognition and cosmopolitanism'. In Festivals and the cultural public sphere, eds. Gerard Delanty, Liana Giorgi, Monica Sassatelli, 108-123. New York: Routledge.

Regis, Helen A. and Shana Walton. 2008. 'Producing the folk at the New Orleans Jazz and Heritage Festival'. Journal of American Folklore 121/482: 400-440.

Rhythm Changes. 2013a. Rhythm Changes: Historical Overviews of Five Partner Countries. Rhythm Changes. Accessed 18-Dec-15. http://www.rhythmchanges.net/wp-content/uploads/2010/10/Historical-ReportWEBSITE.pdf.

Rhythm Changes. 2013b. Rhythm Changes: Statistical Overviews of Five Partner Countries. Rhythm Changes. Accessed 18-Dec-15. 
http://www.rhythmchanges.net/wp-content/uploads/2010/10/Statistical-ReportWEBSITE.pdf.

Riley, Mykaell and Dave Laing. 2006. The Value of Jazz in Britain. Jazz Services. Accessed 08-Aug-15.

https://www.academia.edu/9709384/The Value of Jazz in Britain by Mykael I Riley and Dave Laing.

Riley, Mykaell and Dave Laing. 2010. The Value of Jazz in Britain II. Jazz Services. Accessed 11-Jan-16.

https://www.academia.edu/6553089/Value Of Jazz in Britain 2 the 2008 By Mykaell Riley Dave Laing. Follow up on research first con ducted in 20056.

Ring, Erica M. 2014. Molde Residents' Perceptions on the Social Impacts of Molde International Jazz Festival (Master's diss, Molde University College).

Saayman, Melville and Riaan Rossouw. 2010. 'The Cape Town International Jazz Festival: more than just jazz'. Development Southern Africa 27(2): 255-272.

Saleh, Farouk and Chris Ryan. 1993. 'Jazz and knitwear: factors that attract tourists to festivals'. Tourism Management 14(4): 289-297.

sam and the University of Brighton. 2008. Festivals Mean Business 3: A Survey of Arts Festivals in the UK. British Arts Festivals Association. Accessed 27-Jan16.

http://www.artsfestivals.co.uk/sites/default/files/FMB3\%20Report\%20FINAL3\% 20MAY\%202008.pdf.

Small, Christopher. 1998. Musicking: The Meanings of Performing and Listening. Middletown, Conn.: Wesleyan University Press.

SQW Ltd and TNS Travel and Tourism. 2005. Edinburgh Festivals 2004-2005 Economic Impact Survey. Final Report. Gent, Belgium: European Festivals Association. Accessed 08-Aug-15. http://tinyurl.com/jinp53d.

Stanbridge, Alan. 2008. 'From the margins to the mainstream: jazz, social relations, and discourses of value'. Critical Studies in Improvisation 4(1): 1-18.

Sykes, Tom. 2014. Jazz for the iPod Generation: Music Distribution, Festivals, and Digital Technology (PhD thesis, University of Salford).

Taylor, Tish and Elmarie Slabbert. 2012. 'A cultural profile of tourists to a jazz festival in South Africa' (paper presented at the International Conference On Tourism and Management Studies, Algarve).

Thrane, Christer. 2002. 'Jazz festival visitors and their expenditures: linking spending patterns to musical interest'. Journal of Travel Research 40: 281-286. 
Turner, Victor. 1982. From Ritual to Theater: The Human Seriousness of Play. New York: PAJ Publications.

UK Music. 2011. Destination Music: The Contribution of Music Festivals and Major Concerts to Tourism in the UK: UK Music. Accessed 23-Dec-15. https://www.academia.edu/1765647/Destination Music.

UK Music. 2015. Wish You Were Here 2015: Music Tourism's Contribution to the UK Economy: UK Music. Accessed 23-Dec-15. http://www.ukmusic.org/assets/general/WYWH 2015Report.pdf.

Umney, Charles and Lefteris Kretsos. 2014. 'Creative labour and collective interaction: the working lives of young jazz musicians in London'. Work, Employment and Society 28(4): 571-588.

Van Aalst, Irina and Rianne van Melik. 2011. 'City festivals and urban development: does place matter?' European Urban and Regional Studies 19(2): 195-206.

van Limburg, Bob. 1998. 'City marketing: a multi-attribute approach'. Tourism Management 19(5): 475-477.

Vestrum, Ingebjørg. 2014. 'The embedding process of community ventures: creating a music festival in a rural community'. Entrepreneurship and Regional Development 26(7-8): 619-644.

Vigneault, Stéphane, Bernard Chassé, Laurent Lapierre. 2006. 'Martin Revheim, Bla and the Kongsberg Jazz Festival: suksess need not be translated'. International Journal of Arts Management 8/(2): 62-73.

Vrettos, Alexandros. 2006. The Economic Value of Arts \& Culture Festivals/A Comparison of Four European Economic Impact Studies (Master's diss, University of Maastricht).

Wall, Tim and Andrew Dubber. 2010. 'Experimenting with fandom, live music, and the Internet: applying insights from music fan culture to new media production'. Journal of New Music Research 39(2): 159-169.

Wall, Tim and Paul Long. 2009. 'Jazz Britannia: mediating the story of British jazz on television.' Jazz Research Journal 3(2): 145-170.

Walton, Shana. 2012. "I only go to church once a year": transformation and transcendence in jazz fest narratives'. Southern Journal of Linguistics 36(1): 104-126.

Washburne, Christopher. 2010. 'Jazz re-bordered: cultural policy in Danish jazz'. Jazz Perspectives 4(2): 121-155. 
Webster, Emma. 2011. Promoting Live Music: A Behind-the-Scenes Ethnography (PhD diss, University of Glasgow).

Webster, Emma and George McKay. 2016. From Glyndebourne to Glastonbury: The Impact of British Music Festivals. Norwich: Arts and Humanities Research Council/University of East Anglia.

Wilks, Linda. 2013. 'Exploring social and cultural diversity within "Black British Jazz" audiences'. Leisure Studies 32(4): 349-366.

Williams, Karen and Melville Saayman. 2013. 'Relationship between travel motives and key success factors of visitors at a jazz festival'. South African Journal for Research in Sport, Physical Education and Recreation 35(1): 183-202.

Williams, Raymond. 1958. Culture and Society. London: Hogarth Press. 